\title{
MENGGALI AKAR-AKAR MATERIAL (Maaddah) DAKWAH LINGKUNGAN
}

\author{
Wendi Parwanto \& Ridwan Rosdiawan
}

\begin{abstract}
ABSTRAK
Sebagai agama yang universal/kaaffah, Islam mempunyai konsep yang sangat ideal tentang hubungan manusia dan lingkungan alam sekitar. Manusia dan Alam adalah makhluk integral yang saling bergantung dalam pola kesinambungan, sehingga keberlangsungan hidup manusia sangat tergantung pada bagaimana manusia memperlakukan lingkungannya. Kesadaran ini yang tampaknya kurang dimiliki oleh masyarakat Muslim sehingga dibutuhkan pendekatan dakwah dalam menggugahnya.

Formulasi material (maaddah) dakwah yang berkesadaran lingkungan sangatlah dibutuhkan eksistensinya.
\end{abstract}

Kata Kunci: lingkungan, tafsir, manusia, material)

\section{A. Pendahuluan}

Dewasa ini permasalahan lingkungan hidup telah menjadi trend issu yang sedang booming diperbincangkan karena sangat berkaitan erat dan berpengaruh terhadap kehidupan manusia di berbagai sektor. Perubahan iklim yang ekstrem, pemanasan global serta bencana alam dahsyat dalam skala besar menghiasi halaman depan media-media mainstream dan terjadi hampir di seluruh belahan dunia setiap tahunnya dengan jatuhnya korban yang tidak sedikit.
Kajian lebih jauh dan mendalam terhadap fenomena tersebut hampir semuanya berujung pada satu kesimpulan besar, bahwa ternyata di balik serangkaian bencana yang terjadi adalah ulah dari perbuatan manusia yang kurang arif terhadap lingkungan.

Di Indonesia, berita seputar bencana lingkungan seakan telah menjadi sesuatu yang rutin melintas di perhatian public. Bencana longsor dan banjir bandang seperti yang terjadi di Sumedang dan Garut pada September 2016 lalu, misalnya, tampak sebagai 
sesuatu yang 'normal' di kesadaran audiens sebab pada saat yang sama bencana serupa juga terjadi di wilayah lain di Jawa, Sumatera, Sulawesi dan Maluku. Banjir-banjir yang disebabkan luapan sungai-sungai dan menenggelamkan ratusan rumah penduduk seakan telah menjadi berita rutin media di Indonesia setiap musim penghujan tiba.

Berbagai analisis hampir semua sepakat bahwa issu lingkungan lah yang menjadi penyebab dari semua fenomena tersebut dan pendekatan solusi yang berbasis lingkungan pula lah yang menjadi jawabannya. Namun, kemanakan realisasi dari analisis-analisis solutif tersebut karena bencana lingkungan terus saja berulang? Jawaban umum yang muncul mayoritas mengkambinghitamkan mentalitas dan perilaku masyarakat yang minim kepedulian terhadap pengelolaan lingkungan alam. Penebangan hutan secara liar, pemanfaatan lahan yang serampangan, budaya membuang sampah dan pembuangan limbah industri yang sembaragan adalah beberapa perilaku yang dituding sebagai penyebab kerusakan dan pencemaran lingkungan kemudian berimplikasi pada hancurnya ekosistem air.

Jika mentalitas adalah fokus utama dari penyebab permasalahan lingkungan, maka dibutuhkan sebuah pendekatan solusi yang berangkat dari akar-akar ideologis umum yang banyak dianut dan diyakini oleh masyarakat Indonesia. Masyarakat Indonesia mayoritas menjadikan Islam sebagai agama yang ajarannya menjadi ruh dari mentalitas dan meletakkan dasar ideologis dalam perilaku keseharian. Dengan fakta bahwa lebih dari $80 \%$ penduduk Indonesia adalah Muslim maka menjadi konsekuensi logis jika ajaran Islam juga seharusnya menggugah dan memandu kesadaran masyarakat terhadap kelestarian lingkungan.

Akar-akar kesadaran pelestarian lingkungan dalam Islam pada dasarnya telah begitu gamblang disinyalir oleh sumber-sumber ajarannya, al-Quran dan Sunnah/Hadits. Dalam sebuah hadis panjang yang diriwayatkan oleh Imam Muslim yang menarasikan ketika Jibril bertanya kepada Nabi Saw. tentang alIhsan, kemudian Nabi Saw. menjawab bahwa al-Ihsan adalah apabila kita melakukan suatu ibadah maka hendaklah kita merasa bahwa kita seakan-akan melihat Allah, namun jika kita bisa melihat-Nya, maka yakinlah Allah melihat kita. Al-Ihsan dalam hadis tersebut terdiri dari tiga aspek : Pertama, Ihsan kepada Allah, kedua, Ihsan kepada 
sesama, dan ; ketiga Ihsan kepada alam semesta (lingkungan).

Dalam hal berlaku Ihsan terhadap lingkungan, teks-teks al-Quran dan Hadis yang tersebar berulang kali menekankan bahwa itu merupakan hal yang sangat terpuji, bahwa lingkungan adalah bagian integral dari kehidupan manusia, bahwa memperlakukan lingkungan sebagai suatu komponen ekosistem yang "satu tubuh" dengan manusia sehingga harus senantiasa dihormati, dijaga, dan dilestarikan dalam rangka menggapai kesempurnaan keimanan dank e-Islaman yang kaaffah. Kekayaan konsepkonsep lingkungan tersebut membutuhkan penggalian lebih jauh, sehingga ketika khazanahnya telah tergali maka akan menjadi sarana bagi penyusunan model umum materi yang bisa menggugah dan menjadi pedoman bagi pembangunan mental yang berkesadaran lingkungan.

\section{B. Material Ontologis}

\section{Terminologi}

Menurut pasal 1 Undang-undang nomor 32 tahun 2009 tentang pengelolaan lingkungan hidup, maka lingkungan didefinisikan sebagai kesatuan ruang semua benda, daya, keadaan, makhluk hidup termasuk manusia dan prilakunya, yang mempengaruhi kelangsungan perikehidupan dan kesejahteraan manusia dan makhluk lainnya. Kemudian menurut Siahaan, lingkungan adalah semua benda, daya dan kondisi yang terdapat dalam suatu tempat atau ruang dimana manusia dan makhluk lain berada dan saling memiliki ketergantungan. ${ }^{1}$ Kemudian menurut alQuran, lingkungan atau alam disebut dengan istilah al-'Alamin/al-'Alamun ${ }^{2}$, yang merupakan seluruh kesatuan makhluk hidup yang berada dibumi yang saling memiliki ketergantungan.

Dari beberapa definisi di atas, maka penulis menyimpulkan bahwa lingkungan adalah kombinasi antara dua komponen utama yaitu komponen biotik (benda hidup, termasuk manusia) dan komponen abiotik (benda mati, seperti cahaya, tanah dan lain-lain), dimana antara dua komponen tersebut terdapat sifat saling ketergantungan antar satu dengan yang lain.

\section{Tujuan Penciptaan Lingkungan}

1. QS Al-Jatsiyah (45):13

\footnotetext{
1 N.H. T. Siahaan. Hukum Lingkungan dan Ekologi Pembangunan. Jakarta : Erlangga. 2004, h. 4 ; Jony Purba. Pengelolaan Lingkungan Sosial. Jakarta : Yayasan Obor Indonisia, 2005, h. 13

2 Asy-Syinqithy. Tafsir Adwa' al-Bayan fi Idhah al-Quran bi Al-Quran. Jilid. I. Beirut : Dar Ilmu al-Fawaid. T.th, h. 47
} 


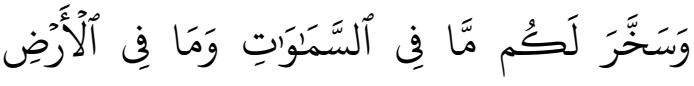

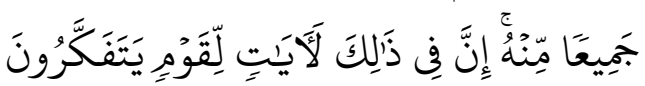

Dan Dia telah menundukkan untukmu apa yang di langit dan apa yang di bumi semuanya, (sebagai rahmat) daripadaNya. Sesungguhnya pada yang demikian itu benar-benar terdapat tanda-tanda (kekuasaan Allah) bagi kaum yang berfikir.

Secara literal, ayat tersebut sudah bisa kita pahami bahwa Allah Swt. menciptakan segala hal yang ada di langit dan di bumi diperuntukan bagi manusia, agar

manusia memanfaatkannya dengan baik sebagai penopang dan penunjang kehidupannya. Quraish Shihab ketika menafsirkan ayat tersebut mengatakan 'Allah yang menjadikan angin sehingga membuat kapal-kapal bisa berlayar sampai ke tempat tujuan walaupun dengan muatan yang sangat berat, Allah menjadikan laut dengan berbagai macam kekayaan di dalamnya, semuanya diperutakan bagi manusia, agar mereka dapat mengambil manfaat dari semua itu'. ${ }^{3}$ Jelas bagi kita, bahwa bumi yang terhampar luas Allah ciptakan bagi kita agar kita senantiasa arif dalam memanfaatkannya sesuai dengan kebutuhan yang kita perlukan tanpa melampau batas, karena Allah

\footnotetext{
${ }^{3}$ Quraish Shihab. Tafsir Al-Misbah: Pesan, Kesan dan Keserasian Al-Quran. Jilid. XII. Jakarta : Lentera Hati. 2002, h. 345
}

tidak menyukai orang-orang yang melampaui batas karena ketamakan dan keserakahannya.

Allah merupakan kreator alam semesta, dan dan Dia lah yang Maha mengetahui apa yang harus la lakukan, selain ayat di atas ${ }^{4}$, mari kita perhatikan ayat berikut :

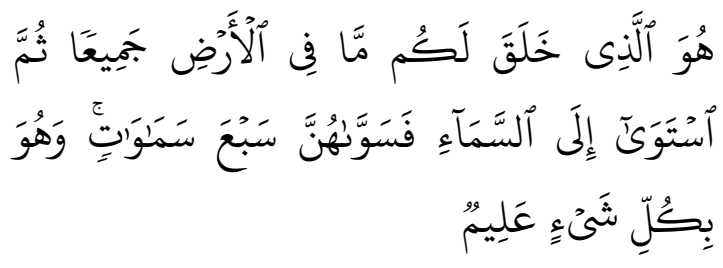

Dia-lah Allah, yang menjadikan segala yang ada di bumi untuk kamu dan Dia berkehendak (menciptakan) langit, lalu dijadikan-Nya tujuh langit. dan Dia Maha mengetahui segala sesuatu. Al-Baqarah (2) : 29

Ayat tersebut senada dengan ayat di atas, perlu ditegaskan bahwa kata "untuk kamu" dalam ayat tersebut memiliki makna yang mendalam dan juga menunjukkan bahwa Allah memberikan kasih sayang yang begitu besar kepada manusia, Allah menjadikan manusia sebagai pengelola alam, Allah berikan kebebasan dan wewenang yang luas kepada manusia untuk memanfaatkan apa yang ada di bumi. Namunselain dari pada itu, manusia juga harus menjaga dan memelihara

${ }^{4}$ QS Al-Jatsiyah (45):13 
kelestarian alam. Terkait manusia sebagai pusat pengelola alam, maka wajar ketika menafsirkan ayat tersebut Hamka mengatakan 'manusia sebagai sayyid (Tuan/majikan) bagi bumi dan majikan bagi alat atau sarana, manusia bukan sebagai alat bagi alat seperti yang terjadi di dunia matrealis sekarang ini'. ${ }^{5}$

$\begin{array}{ccc} & \text { Setelah alam disajikan Allah } \\ \text { untuk manusia, maka } & \text { Allah }\end{array}$
mengingatkan kembali agar manusia senantiasa tidak melupakan kewajibanya sebagai hamba Allah yaitu mencari kebahagian akhirat dengan memperbanyak amal ibadah. Allah berfirman :
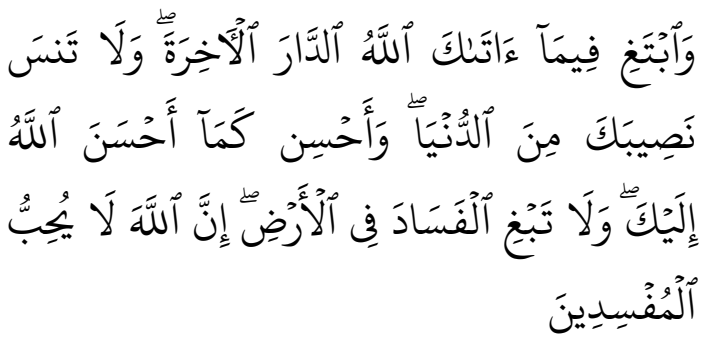

Dan carilah pada apa yang telah dianugerahkan Allah kepadamu (kebahagiaan) negeri akhirat, dan janganlah kamu melupakan bahagianmu dari (kenikmatan) duniawi dan berbuat baiklah (kepada orang lain) sebagaimana Allah telah berbuat baik, kepadamu, dan janganlah kamu berbuat kerusakan di (muka) bumi. Sesungguhnya Allah tidak menyukai orang-orang yang berbuat kerusakan. (Qs. Al-Qashshash (28) : 77.

\footnotetext{
${ }^{5}$ Sayyid Quthb. Tafsir Fi Dzilal Al-Quran. Terj. Jilid. I. Jakarta : Gema Insani. 2000, h. 90-91
}

Salah satu sarana yang dapat menghantarkan manusia untuk dapat merasakan manisnya kehidupan akhirat adalah dengan cara memanfaatkan alam dengan sebaik-baiknya. Dan ayat tersebut dikatakan "Jangan melupakan bagian duniawi", Al-Baidhawi ketika menafsirkan ayat tersebut mengatakan bahwa 'Hendaknya kita tidak meninggalkan bagian dunia, karena dunia merupakan sarana yang dapat menunjang kesuksesan akhirat'. 6 Dengan demikian, alam memiliki peranan penting dalam kehidupan manusia, selain sebagai penuhan kebutuhan manusia, alam juga dapat dijadikan sebagai sarana yang dapat mengantarkan kepada kebahagian sejati di sisi Allah kelak. Oleh karena itu, mengingat pentingnya alam dalam ayat tersebut ditutup dengan "Janganlah kamu berbuat kerusakan di (muka) bumi. Sesungguhnya Allah tidak menyukai orang-orang yang berbuat kerusakan", ini mengsignalir bahwa betapa pentingnya menjaga kelestarian alam dengan tidak mengeksploitasi secara berlebihan.

\section{Material Epistemologis 1. Interaksi Manusia dan Alam}

\footnotetext{
${ }^{6}$ Al-Baidhawi. Anwar At-Tanzil wa Asrar AtTakwil. Jilid. II. Beirut : Dar Al-Kutub AlIlmiyyah. 1988, h. 200
} 
Secara kasat mata, kerusakan lingkungan/alam terjadi karena perubahan iklim atau cuaca. Namun, jika ditelaah lebih jauh maka kita akan menemukan bahwa rusaknya alam adalah karena perbuatan manusia. Ketika manusia melakukan hal-hal yang positif terhadap alam, maka akan menciptakan alam/ lingkungan baik dan kondusif. namun sebalikny, jika manusia melakukan hal-hal yang negatif terhadap alam, maka akan tercipta lingkungan yang buruk, bahkan bisa sampai membunuh manusia dalam lingkungan tersebut.

Ketamakan dan keserakahan manusia yang biasanya menjadi faktor utama yang menyebabkan manusia berani mengambil tindakan frontal terhadap alam ${ }^{7}$, tanpa menyadari bahwa alam pun bisa murka terhadap perlakuan manusia yang demikian. Allah berfirman dalam surat Asy-Syura' (42) : 27 :

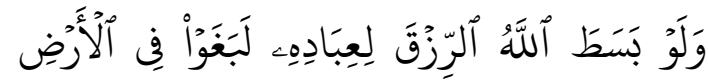

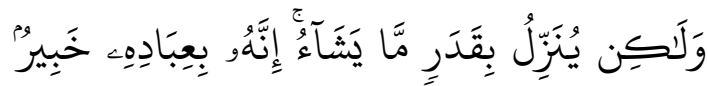

Dan Jikalau Allah melapangkan rezki kepada hamba-hamba-Nya tentulah mereka akan melampaui batas di muka bumi..,

\footnotetext{
${ }^{7}$ Hasbi Ash-Shiddieqy, Tafsir Al-Majid. Jakarta : Bulan Bintang. 1965, h. 61
}

Dalam ayat di atas jelas memberikan gambaran kepada kita bahwa apabila sifat ketamakan dan keserakahan telah melekat pada manusia maka ia akan melalukan berbagai hal agar keinginannya tersebut tercapai. Demikian halnya dengan pemanfaatan alam, manusia yang serakah dan tamak akan kekayaan alam maka ia akan mengeksploitasi alam dengan membabi buta, tanpa memperhatikan akibat dari perbuatannya. Implikasi dari keserakahan dan ketamakan manusia itu lah yang meyebabkan alam murka, banjir terjadi akibat hutan dibabat habis dan pembuangan sampah yang sembarangan, tanah longsor akibat penggundulan hutan tanpa reboisasi, hancurnya ekosistem air akibat pembuangan limbah pabrik dan limbah rumah tangga yang sembarangan, terjadinya kebaaran hutan akibat ulah manusia yang melakukan praktek ladang berpindah, dan kerusakan-kerusakan alam lainnya. Oleh karena itu, maka wajar jika al-Quran mengatakan bahwa hancurnya alam di daratan maupun di lautan merupakan akibat dari ulah manusia :

Telah nampak kerusakan di darat dan di laut disebabkan karena perbuatan tangan manusi, supay Allah merasakan kepada mereka sebahagian dari (akibat) 
perbuatan mereka, agar mereka kembali (ke jalan yang benar).

Dalam ayat tersebut Allah Swt. menjelaskan dengan tegas bahwa kerusakan di daratan dan di lautan adalah akibat dari ulah perbuatan manusia. Ketikan merujuk pada tafsir salaf (klasik), maka yang dimaksud dengan 'kerusakan' pada ayat di atas adalah syirik $^{8}$, dzalim dan kesesatan ${ }^{9}$, Namun, jika kita merujuk pada tafsir ulama khallaf (kontemporer), maka makna 'kerusakan' tersebut adalah kerusakan lingkungan hidup. Kemudian menurut Al-Wahidiy, makna 'oleh perbuatan tangan manusia', menurutnya adalah kerusakan yang dilakukan oleh orang-oramng kafir Mekkah. ${ }^{10}$

Oleh karena itu, untuk menambah kejelasan interpretasi ayat di atas, Qurais Shihab selaku mufassir kontemporer, ketika menafsirkan ayat tersebut beliau memulai dengan kajian linguistik, ketika mengurai makna 'Dzahara', menurutnya, kata dzahara bererti 'sesuatu yang terjadi dipermukaan bumi', kemudian kata 'alFasad mengandung arti keluarnya

\footnotetext{
${ }^{8}$ Ibnu Katsir. Tafsir Al-Quran Al- 'Adzim. Jilid. 3. Bairut : Maktabah Nur al-Ilmiyyah. 1992, h. 420

${ }^{9}$ Al- Baidhawi. Anwar At-Tanzil wa Asrar AtTakwil. Jilid. II. Beirut : Dar al-Ilmiyyah. 1988, h. 222

${ }^{10}$ Ahmad Wahidiy An-Naisaburiy. Al-Wasith fi Tafsir al-Quran Al-Majid. Jilid. III. Beirut : Dar al-Kutub al-Ilmiyyah. 1994, h. 435
}

sesuatu dari keseimbangan, baik itu sedikit maupun banyak. ${ }^{11}$

Untuk memperjelas pendapat Quraish Shihab di atas, maka penulis kemukan penafsiran Al-Maraghi ketika menafsirkan ayat tersebut ia mengatakan 'al-Fasad' (kerusakan), kerusakan yang diterangkan dalam ayat tersebut merupakan kerusakan secara umum yang terjadi di daratan dan di lautan, namun diperjelas bahwa berbagai perbuatan yang tercela yang terjadi di muka bumi merupakan suatu bentuk kerusak yang dilakukan oleh manusia, seperti ; mengkonsumsi narkoba, psikotropika dan zat adiktif yang merupakan pemicu rusaknya generasi, melakukan perzinaan yang akan merusak keturuanan, pencurian yang merugikan pihak lain dan perbuatanperbuatan tercela lainnya, itu semua tercakup dalam makna al-Fasad. ${ }^{12}$

Islam mewajibkan berlaku baik kepada alam semesta. Oleh karena itu, banyak ayat di dalam al-Quran yang melarang berbuat kerusakan di atas permukaan bumi. Allah berfirman :

Dan janganlah kamu membuat kerusakan di muka bumi, sesudah (Allah)

\footnotetext{
11 Quraish Shihab. Tafsir Al-Misbah : Pesan, Kesan dan Keserasian Al-Quran. Jilid. XI. Jakarta : Lentera Hati. 2002, h. 76

12 Ahmad Mustafa Al-Maraghi. Tafsir AlMaraghi. Jilid. VIII. Terj. Semarang : Toha Putra. 1988, h. 330
} 
memperbaikinya dan Berdoalah kepadaNya dengan rasa takut (tidak akan diterima) dan harapan (akan dikabulkan). Sesungguhnya rahmat Allah Amat dekat kepada orang-orang yang berbuat baik.

Oemar Bakri ketika menafsirkan ayat tersebut mengatakan manusia dilarang keras membuat kerusakan di muka bumi, ketenteraman, kemakmuran, dan kebahagaiaan harus diciptakan dengan berupaya untuk tidak mengusik lingkungan, peperangan,perkelahian, membuat senjata untuk menghancurakan bumi, merupaka perbuatan yang tercela dan dilarang. ${ }^{13}$

Melaui dua dalil di atas, penulis menyimpulkan bahwa kerusakan dan kehancuran permukaan bumi merupakan ulah dari perbuatan manusia yang tidak bertanggung jawab dalam memanfaatkan alam, kurang cermat serta kurang peka terhadap alam. Sehingga bencana terjadi dimana-mana. Seperi terjadi banjir akibat eksploitasi hutan dengan membabi buta, banjir juga di akibatkan oleh pembuangan sambah yang sembarangan, dan kerusakankerusakan lainnya, tanpa di sadari halhal yang kita lakukan tersebut akan merugikan diri kita sendiri bahkan bisa

\footnotetext{
${ }^{13}$ Oemar Bakri. Tafsir Rahmat. Jakarta : Mutiara. 1982, h. 297
}

sampai membunuh masyarakat di lingkungan tersebut.

Dalam hal ini hukum kausalitas terlihat jelas, seperti banjir yang banyak melanda di sebagian wilayah Indonesia, dan faktor utama penyebab banjir tersebut adalah dibukan dan tidak lain karena masyrakat sekitar kurang arif terhadap lingkungan, dengan membuang sampah secara sembarangan sehingga terjadinya penimbunan parit maupun sungai, jika hal terbut terjadi maka bencana pun akan terjadi, bukan hanya banjir, dan kehilangan harta benda, namun penyakit pun mudah menular, terlebih lag nyawa pun bisa melayang.

Oleh karena itu, teringat pepatah para tetua dahulu mengatakan 'Jangan pernah main api jika tidak mau terbakar', artinya jangan pernah mengusik alam/lingkungan jika kita tidak ingin alam murka terhadap kita, berlaku baik lah terhadap alam, lestarikan alam, lindungi marga atau satwa yang ada di alam, maka hidup kita akan tenteram dan damai. Manusia merupakan makhluk kreatif dan inovatif dengan dianugerahkan akal fikiran, selayaknya kita dapat memanfaatkan alam dengan sebaik-baiknya, sehingga alam bukan hanya sebagai sarana pemenuhan kebutuhan, namun juga berguna untuk mengasah kreativitas dan inovasi kita di era modern sekarang ini, seperti belajar 
memanfaatkan barang-barang bekas untuk dijadikan barang yang bernilai ekonomis.

\section{Ancaman Pelanggaran}

1. Menurut Hukum Positif

Undang-undang yang mengatur tentang lingkungan adalah UU Nomor 23 tahun 2009. Adapun perusakan lingkungan hidup didefinisikan sebagai tindakan orang yang menimbulkan perubahan langsung atau tidak langsung terhadap sifat fisik, kimia, dan/atau hayati lingkungan hidup sehingga melampaui kriteria baku kerusakan lingkungan hidup.

Adapun sanksi yang diberikan bagi perusak lingkungan adalah hukuman terberat bagi perusak lingkungan hidup adalah dipidana dengan pidana penjara paling lama 15 (lima belas) tahun dan denda paling banyak Rp. 15.000.000.000,00 (lima belas miliar rupiah). Selain itu, terhadap badan usaha dapat dikenakan pidana tambahan atau tindakan tata tertib berupa : (a) perampasan keuntungan yang diperoleh dari tindak pidana; (b) penutupan seluruh atau sebagian tempat usaha dan/atau kegiatan; (c) perbaikan akibat tindak pidana; (d) pewajiban mengerjakan apa yang dilalaikan tanpa hak; dan/atau (e) penempatan perusahaan di bawah pengampuan paling lama 3 (tiga) tahun. ${ }^{14}$

2. Menurut al-Quran

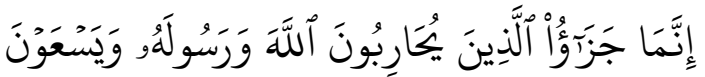

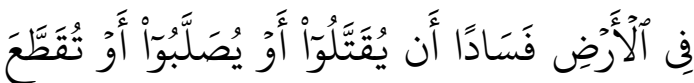

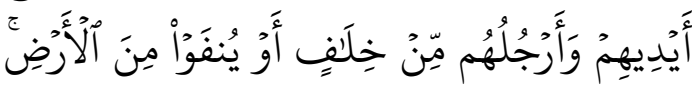

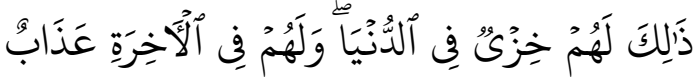
عَظِيمُ Sesungguhnya pembalasan terhadap orang-orang yang memerangi Allah dan Rasul-Nya dan membuat kerusakan di muka bumi, hanyalah mereka dibunuh atau disalib, atau dipotong tangan dan kaki mereka dengan bertimbal balik, atau dibuang dari negeri (tempat kediamannya). yang demikian itu (sebagai) suatu penghinaan untuk mereka didunia, dan di akhirat mereka beroleh siksaan yang besar. (Qs. AlMaidah (5) : 33).

Dalam ayat tersebut, had atau hukuman bagi penjahat lingkungan sangat berat ini dibuktikan dengan pelaku perusak lingkungan disamaratakan dengan orang yang memerangi Allah dan Rasul. Oleh karena itu, had atau hukuman yang ditegas di dalam alQuran bagi penjahat lingkungan adalah

\footnotetext{
14 http://www.kompasiana.com/lhapiye/terlaluringankah-hukuman-bagi-kejahatanlingkungan 5638acd3729773ee096dc55a (diakses, 27 Oktober 2016, pukul 10.33 Wib)
} 
dibunuh atau disalib. Melalui ultimatum al-Quran demikian, maka sangat jelas Islam sangat memperhatikan akhlak manusia terhadap lingkungan, karena lingkungan merupakan bagian dari integritas seluruh civitas kehidupan manusia di permukaan bumi.

\section{Material Aksiologis}

\section{Sikap Hormat Terhadap Alam (Respect For Nature)}

Qs. Al-Anbiya (21) : 107

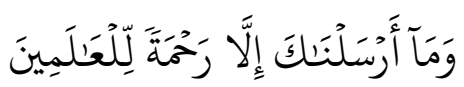

Dan Tiadalah Kami mengutus kamu, melainkan untuk (menjadi) rahmat bagi semesta alam.

Secara esensial, ayat tersebut menerangakan tantang tujuan diutusnya Nabi Muhammad Saw. ke permukaan bumi, namun jika dipahami secara mendalam, ayat tersebut mengisyaratkan bahwa hendaknya manusia senantiasa meneladani prilaku Nabi Muhammad Saw. dalam setiap roda kehidupan. Sebelum Eropa mengenal organisasi pencinta satwa, maka jauh sebelum itu Nabi Saw. telah mengajarkan kepada kita bagaimana seyogyanya kita memperlakukan bintang dan lingkungan sekitar. Contoh ; Nabi Saw. melarang memetik bunga sebelum mekar, melarang memetik buah sebelum matang, melarang menyembelih dengan pisah yang tumpul dan lain sebagainya. ${ }^{15}$ Kepribadian Nabi Saw. ini menunjukkan bahwa betapa pentingnya kita menjaga dan melestarikan kelangsungan ekosistem yang terdapat di alam. Oleh karena itu, kita perlu menyadari dan menumbuhkan rasa hormat, rasa respect terhadap alam. ketika rasa itu telah tumbuh dan mengakar dalam diri kita, maka kenyamanan dan ketenteraman di alam akan tercipta.

\section{Prinsip Tanggung Jawab (Moral Responsibility For Nature)}

Qs. Al-Baqarah (2) : 30

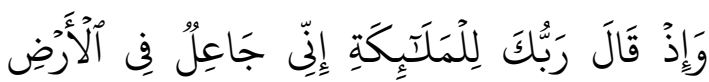

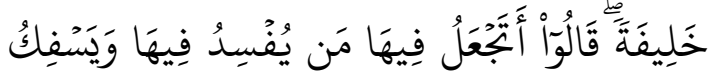

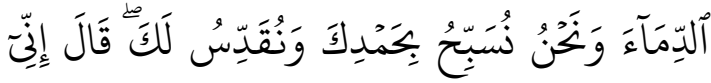

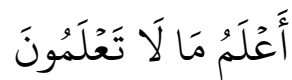
Dan ingatlah ketika Tuhanmu berfirman kepada Para Malaikat: "Sesungguhnya aku hendak menjadikan seorang khalifah di muka bumi." mereka berkata: "Mengapa Engkau hendak menjadikan (khalifah) di bumi itu orang yang akan membuat kerusakan padanya dan menumpahkan darah, Padahal Kami Senantiasa bertasbih dengan memuji Engkau dan mensucikan Engkau..,"

\footnotetext{
${ }^{15}$ Quraish Shihab. Tafsir Al-Misbah : Pesan, Kesan dan Keserasian Al-Quran. Jilid. XI. Jakarta : Lentera Hati. 2002, h. 134-135
} 
Yang menjadi stressing penting dalam ayat tersebut adalah kata khalifah, jika ditinjau dari segi defini linguistik, maka makna khalifah adalah 'mengganti apa yang telah ada sebelumnya'. ${ }^{16}$ Berbagai pendapat muncul ketika menginterpretasikan kata khalifah dalam ayat tersebut. Ada yang menafsirkan bahwa khalifah dalam ayat tersebut adalah Nabi Adam as, ada juga Nabi Daud as. dan berbagai wajah penafsiran lainnya. Namun, ketika merujuk pada mufassir kontemporer, maka makna khalifah dalam ayat tersebut adalah seluruh manusia yang hidup dibumi. ${ }^{17}$

Allah Swt. memberikan limpahan wewenang kepada manusia untuk menjadi pemimpin di alam raya ini, dengan kata lain manusia merupakan

${ }^{16}$ Quraish Shihab. Tafsir Al-Misbah : Pesan, Kesan dan Keserasian Al-Quran. Jilid. I. Jakarta : Lentera Hati. 2002, h. 172-173

17 Terkait kata khalifah (pemimpin), maka perlu dipahami bahwa khalifah bukan hanya pemimpin negara, pemimpin agama, atau pemimpin masyarakat. Namun, terminologi dari kata khalifah tersebut mencakup makna yang cuku luas, termasuk pemimpin dalam keluarga, pemimpin dalam organisasi kecil dan pemimpin-pemimpin dalam berbagai hal lainnya. Oleh karena itu, dalam suatu hadits yang shahih dikatakan bahwa "Setiap kamu adalah pemimpin, maka kelak setiap pemimpin akan dimintai pertanggung-jawban, seorang ayah merupakan pemimpin bagi keluargannya, Ibu adalah pemimpin bagi anak-anaknya, dan lebih jauh lagi, seorang pembantu pemimpin (penjaga) harta majikannya”. ; Quraish Shihab. Membumikan Al-Quran : Fungsi dan Peran Wahyu dalam Kehidupan Masyarakat. Bandung : Mizan, 1992, h. 460 delegasi Allah di muka bumi, ini bukan berarti Allah tidak mampu mengurusnya, namun dengan melimpahkan wewenang ini Allah ingin menunjukkan sifat-Nya yang maha rahman dan maha rahim terhadap manusia. Manusia sebagai delegasi Allah, bukan dalam artian sebagai kreator alam, namun sebagai pengelola alam untuk dimanfaatkan sesuai dengan kebutuhan. Terminologi kata khalifah dalam ayat di atas mengandung pengertian yang sangat luas, bukan hanya pemerintah, namun rakyat biasa juga merupaka khalifah fi alArd (pemimpin di muka bumi). Oleh karena itu, prinsip tanggung jawab terhadap alam harus kita tanamkan dalam hati kita masing-masing, baik kita selaku pemimpin negara, aparatur negara, bahkan rakyat kecil sekalipun, maka konsep tersebut harus senantiasa kita pegang. Jika kita hanya berpatokan terhadap peraturan pemerintah tanpa ada kesadaran dari diri kita, maka kelestarian lingkungan/alam tidak akan tercipta. Namun, apabila konsep atau prinsip tanggung jawab tersebut telah tertanam dalam di jiwa kita, maka kelestarian alam ketenteraman alam/lingkungan akan terwujud. Sebagai motivasiuntuk menumbuhkan prinsip tanggung jawab terhadap alam, maka perlu selalu diingat setiap perbuatan yang kita lakukan tidak lepas dari 
monitoring Allah Swt. dan kelak akan dipertanggung jawabkan di hadapanNya. Selanjutnya, tegasnya hancur atau tidaknya alam ini tergantung kita sebagai 'manager utama' dalam mengelola dan memanfaatkannya.

\section{Prinsip Kasih Sayang dan Kepedulian Terhadap Alam (Caring For Nature)}

Hadits :

Prinsip kasih sayang terhadap lingkungan telah banyak diilustrasikan oleh Rasulullah Saw. dalam setiap lintasn kehidupan beliau, seperti yang telah penulis paparkan dalam penjelasan ayat al-Anbiya' 107 di atas. Kemudian contoh lainnya dalam sabda Beliau :

1. Larangan Menelantarkan Lahan

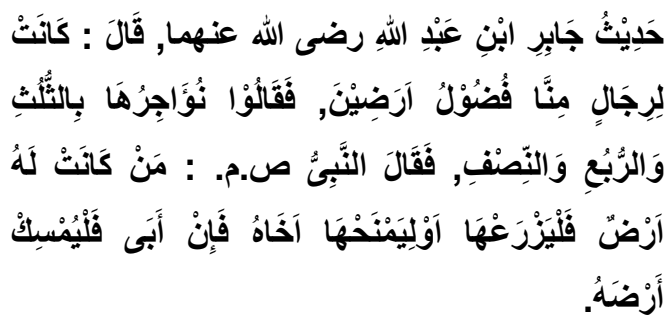

Hadist Jabir bin Abdullah r.a. dia berkata : Ada beberapa orang dari kami mempunyai simpanan tanah. Lalu mereka berkata: Kami akan sewakan tanah itu (untuk mengelolahnya) dengan sepertiga hasilnya, seperempat dan seperdua. Rosulullah S.a.w. bersabda: Barangsiapa ada memiliki tanah, maka hendaklah ia tanami atau serahkan kepada saudaranya (untuk dimanfaatkan), maka jika ia enggan, hendaklah ia memperhatikan sendiri memelihara tanah itu. “ (HR. Imam Bukhori dalam kitab Al-Hibbah)

2. Perintah Menggalakan

Reboisasi

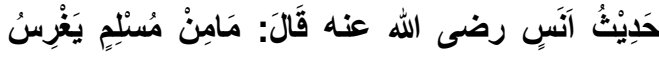

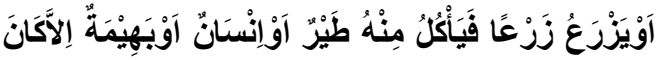

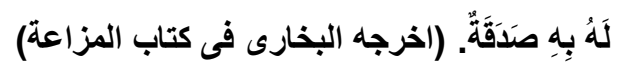
Hadits dari Anas r.a. dia berkata: Rosulullah S.a.w. bersabda: Seseorang muslim tidaklah menanam sebatang pohon atau menabur benih ke tanah, lalu datang burung atau manusia atau binatang memakan sebagian daripadanya, melainkan apa yang dimakan itu merupakan sedekahnya “. (HR. Imam Bukhori dalam Bab Mazra'ah)

Menurut hemat penulis, dua hadits tersebut sudah cukup refresentatif untuk mengilustrasikan bagaimana Nabi Saw. sangat perhatian kelestarian alam. Oleh karena itu, kita selaku umatnya sudah sepantasnya kita meneladani sifat beliau, minimal dengan melakukan halhal kecil yang memberikan dampak yang baik terhadap lingkungan.

\section{E. Penutup}


Berdasarkan paparan di atas, material (maadah) Dakwah lingkungan seharusnya bisa dicarikan formulasi dan sistematisasinya. Kategorisasi di atas diatur berdasarkan hierarki yang modelnya diambil dari pola umum objek formal yang biasa digunakan sebagai pendekatan dalam alternative menemukan sistematisasi baru. Tentu saja, pendekatan lain yang lebih efektif dan efisien bisa saja dipergunakan. Tetapi yang penting usaha tersebut bisa mengarah kepada formulasi maaddah Dakwah yang bisa dijadikan pedoman dalam menggugah kesadaran lingkungan.

Karakteristik dari materialmaterial dakwah seharusnya mampu menyentuh nilai-nilai umum kesadaran lingkungan Islami yang bisa disimpulkan memenuhi kriteria pandangan seperti di bawah ini:

1. Lingkungan merupakan suatu kesatuan ekosistem yang luas, dimana seluruh komponen yang ada di dalamnya saling memiliki ketrergantungan.

2. Alam/lingkungan diciptakan Allah Swt. untuk manusia, dan manusia diberikan wewenang dalam mengelolanya.

3. Faktor utama penyebab kerusakan alam/lingkungan adalah perbuatan manusia yang melampaui batas dan tidak bertanggung jawab.

4. Solusi penanggulangan kerusakan lingkungan harus mempertimbangkan; 1). Menanamkan Sikap Hormat Terhadap Alam (Respect For Nature). 2). Prinsip Tanggung Jawab (Moral Responsibility For Nature). 3). Prinsip Kasih Sayang dan Kepedulian terhadap Alam (Caring For Nature)

Tulisan ini adalah sebuah usaha eksploratif yang mencoba menjembatani antara kebutuhan mendesak pembangunan kesadaran lingkungan di tengah masyarakat Indonesia yang mayoritas Muslim dengan fakta minimnya panduan sistematis material Dakwah lingkungan yang disebabkan oleh tersebarnya konsep-konsep yang sebetulnya kaya dengan nilai-nilai Ketuhanan. Karena sifatnya yang eksploratif, sudah barang tentu dalam tulisan ini masih banyak kekuarangan sehingga masih sangat jauh dari kesempurnaan. Koreksi dan perluasan wawasan sangat diperlukan demi terformulasikannya material dakwah lingkungan yang mencerahkan dan menginspirasi dalam menjawab permasalahan-permasalahan bencana alam yang sudah cenderung kompleks.

\section{F. Daftar Pustaka}


Ahmad Mustafa Al-Maraghi. Tafsir AlMaraghi. Jilid. VIII. Terj. Semarang : Toha Putra. 1988

Ahmad Wahidiy An-Naisaburiy. AlWasith fi Tafsir al-Quran Al-Majid. Jilid. III. Beirut : Dar al-Kutub alIImiyyah. 1994

Al-Baidhawi. Anwar At-Tanzil wa Asrar At-Takwil. Jilid. II. Beirut : Dar AlKutub Al-IImiyyah. 1988

Asy-Syinqithy. Tafsir Adwa' al-Bayan fi Idhah al-Quran bi Al-Quran. Jilid. I. Beirut : Dar IImu al-Fawaid. T.th

Hasbi Ash-Shiddieqy, Tafsir Al-Majid. Jakarta : Bulan Bintang. 1965

Ibnu Katsir. Tafsir Al-Quran Al-'Adzim. Jilid. 3. Bairut : Maktabah Nur alIlmiyyah. 1992

Jony Purba. Pengelolaan Lingkungan Sosial. Jakarta : Yayasan Obor Indonisia, 2005

N.H.T. Siahaan. Hukum Lingkungan dan Ekologi Pembangunan. Jakarta : Erlangga. 2004

Oemar Bakri. Tafsir Rahmat. Jakarta : Mutiara. 1982

Sayyid Quthb. Tafsir Fi Dzilal Al-Quran. Terj. Jilid. I. Jakarta : Gema Insani. 2000

Quraish Shihab. Tafsir Al-Misbah : Pesan, Kesan dan Keserasian AlQuran. Jilid. I, IV, VIII, IX, XI, Jakarta : Lentera Hati. 2002 http://www.kompasiana.com/lhapiye/terla lu-ringankah-hukuman-bagikejahatanlingkungan_5638acd3729773ee09 $6 d c 55 a$ 